Article

\title{
Synthesis and Photophysical Study of 2'-Deoxyuridines Labeled with Fluorene Derivatives
}

\author{
Hyun Yi Cho ${ }^{1}$, Sang Keun Woo ${ }^{2, *}$ and Gil Tae Hwang ${ }^{1, *}$
}

1 Department of Chemistry and Green-Nano Materials Research Center, Kyungpook National University, Daegu 702-701, Korea; E-Mail: whgusd1840@hanmail.net

2 Molecular Imaging Research Center, Korea Institute of Radiological and Medical Sciences, 75 Nowon-gil, Seoul 139-706, Korea

* Authors to whom correspondence should be addressed; E-Mails: skwoo@kcch.re.kr (S.K.W.); giltae@knu.ac.kr (G.T.H.); Tel.: +82-2-970-1659 (S.K.W.); Fax: +82-2-970-1341 (S.K.W.); Tel.: +82-53-950-5331 (G.T.H.); Fax: +82-53-950-6330 (G.T.H.).

Received: 14 September 2012; in revised form: 3 October 2012 / Accepted: 10 October 2012 / Published: 15 October 2012

\begin{abstract}
We examined microenvironment-sensitive fluorescent 2'-deoxyuridines labeled with fluorene derivatives that exhibited solvent-dependent photophysical properties. The high sensitivity of the fluorescence shift and the nucleoside intensity dependence on solvent polarity provided information useful for estimating the polarity of the environment surrounding the fluorescent nucleoside.
\end{abstract}

Keywords: nucleosides; fluorene; fluorescence; dibenzofuran; dibenzothiophene

\section{Introduction}

Fluorescent nucleosides which are structurally noninvasive, forming stable Watson-Crick base pairs, and sensitive to their physical conditions and molecular species in solution, exhibiting environmental-specific changes in their fluorescent properties, have become powerful tools for the investigation of nucleic acid structure, recognition of single nucleotide polymorphisms (SNPs), and studies on enzymatic processes involving DNA [1-8].

In order to design fluorescent nucleosides, we utilized an ethynyl linker at the 5 position of uracil to maintain the hybridization properties of the parent nucleoside. This substitution is expected to have very little influence on the stability of the resulting duplex DNA [9-20]. Among fluorophores, fluorene 
derivatives have moderate quantum yields and are less bulky than other commonly used fluorophores, e.g., pyrene, fluorescein, rhodamine, and cyanine dyes [21]. Previously, we reported fluorene (FL)and 9-fluorenone (FO)-labeled deoxyuridine ( $\mathbf{U}^{\mathrm{FL}}$ and $\mathbf{U}^{\mathrm{FO}}$ ), which we incorporated at the central positions of oligodeoxynucleotides in an attempt to examine the effect of electronic modification of the fluorophore scaffold on the potential of the molecular beacon (MB) for SNP typing (Figure 1) [9-11]. When such a quencher-free MB hybridizes with its perfectly matched target DNA, it exhibits strong fluorescence. In contrast, when it forms duplexes with single-base-mismatched target DNAs, the $\mathbf{U}^{\mathrm{FL}}$ and $\mathbf{U}^{\mathbf{F O}}$ units display quenched fluorescence as a result of photoinduced charge transfer originating from interactions with neighboring nucleobases. These changes in fluorescence are extremely dependent on the electronic and conformational microenvironments of the flanking bases. Therefore, we sought to synthesize other fluorescent uridines labeled with new FL derivatives, dibenzofuran (DBF) and dibenzothiophene (DBT), in order to examine changes in their photophysical properties through modifications of the fluorene unit and to develop these nucleosides as microenvironmentsensitive fluorescent nucleosides $[17,22,23]$. Although FL, FO, DBF, and DBT are structural analogs that differ only in the type of atoms bridging the two aromatic rings, they have dramatically different photophysical properties [24-26]. Here, we report the synthesis and photophysical properties of fluorescent FL derivative-conjugated 2'-deoxyuridine analogs.

Figure 1. Fluorescent nucleosides used in this study.
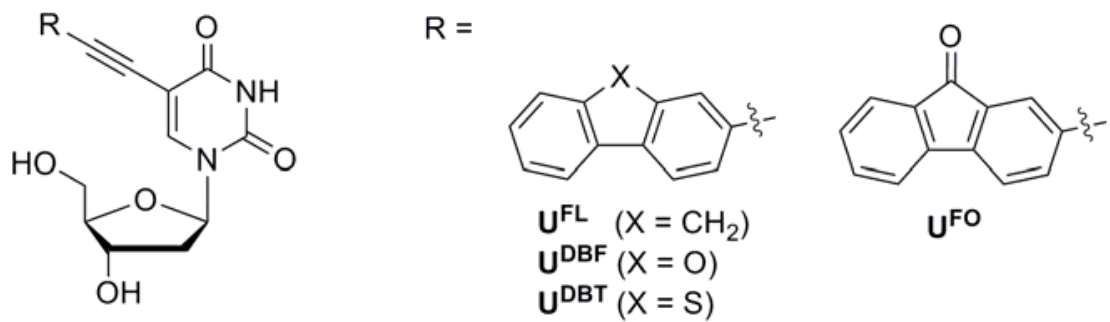

\section{Results and Discussion}

The synthetic route of the DBF- and DBT-labeled $2^{\prime}$-deoxyuridine derivatives $\mathbf{U}^{\text {DBF }}$ and $\mathbf{U}^{\text {DBT }}$ is outlined in Scheme 1. 3-Ethynyldibenzofuran (3a) was prepared by $\mathrm{Pd} / \mathrm{Cu}$-catalyzed Sonogashira coupling [27,28] of 3-bromodibenzofuran (1) with trimethylsilylacetylene followed by desilylation. 3-Ethynyldibenzothiophene (3b) was also synthesized according to the reported protocol [29]. We synthesized $\mathbf{U}^{\text {DBF }}$ and $\mathbf{U}^{\text {DBT }}$ from the corresponding 2'-deoxy-5-iodouridine (4) through a palladium catalyzed cross-coupling reaction with 3-ethynyldibenzofuran (3a) or 3-ethynyldibenzothiophene (3b). The syntheses of $\mathbf{U}^{\mathbf{F L}}$ and $\mathbf{U}^{\mathrm{FO}}$ were conducted as reported [9-11].

Generally, solvent polarity is of primary interest when considering environmental effects [30]. Therefore, we first measured the absorption and emission spectra of nucleosides in thirteen solvents of different polarities. Solvent marginally affected the absorption, probably due to the weak interaction between the nucleosides and solvent in the ground state (Figure 2). However, solvent polarity had a significant influence on both the emission maximum and intensity (Figure 3). All nucleosides exhibited different emission intensities and maxima depending on the solvent they were in, indicating that they are all environmentally sensitive. 
Scheme 1. Route for the synthesis of $\mathbf{U}^{\text {DBF }}$ and $\mathbf{U}^{\text {DBT }}$.

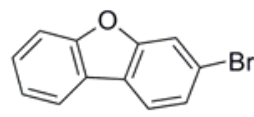

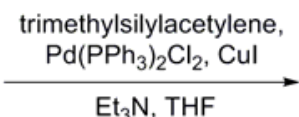

$50^{\circ} \mathrm{C}, 4 \mathrm{~h}$

$61 \%$

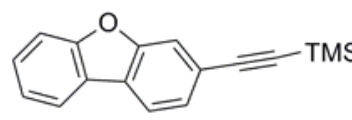

2

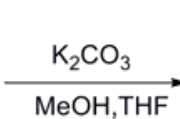

$\mathrm{rt}, 5 \mathrm{~h}$

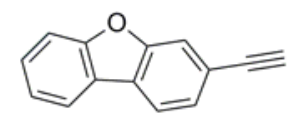

$3 a$

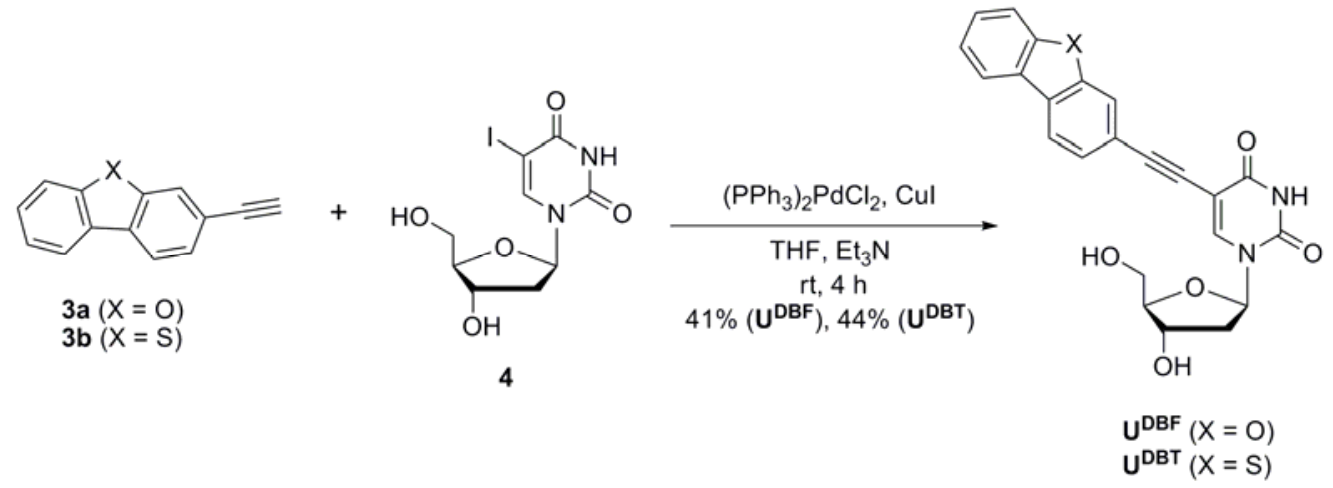

Figure 2. Absorption spectra of (a) $\mathbf{U}^{\mathrm{FL}}(3 \mu \mathrm{M}),(\mathbf{b}) \mathbf{U}^{\mathrm{FO}}(3 \mu \mathrm{M}),(\mathbf{c}) \mathbf{U}^{\mathrm{DBF}}(5 \mu \mathrm{M})$, and (d) $\mathbf{U}^{\text {DBT }}(5 \mu \mathrm{M})$ in different solvents at $25{ }^{\circ} \mathrm{C}$. All samples contain $0.5 \% \mathrm{THF} / \mathrm{MeOH}$ $(1: 1 \mathrm{v} / \mathrm{v})$ to ensure solubility.
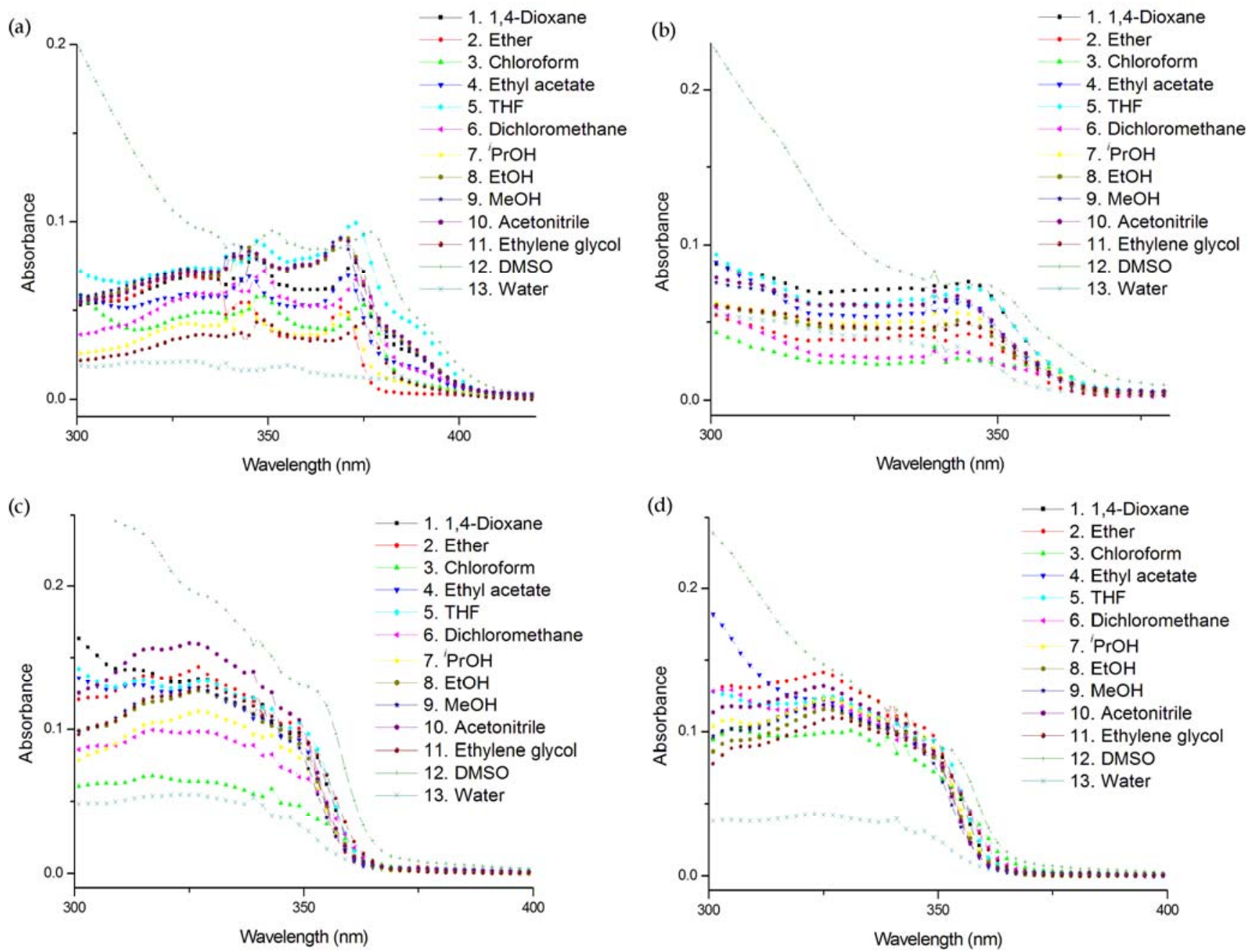
Figure 3. Emission spectra of (a) $\mathbf{U}^{\mathrm{FL}}$, (b) $\mathbf{U}^{\mathrm{FO}}$, (c) $\mathbf{U}^{\mathrm{DBF}}$, and (d) $\mathbf{U}^{\mathrm{DBT}}$ in different solvent at $25^{\circ} \mathrm{C}$ (all at $3 \mu \mathrm{M}$ concentration). The excitation wavelengths were $370 \mathrm{~nm}$ for $\mathbf{U}^{\mathbf{F L}}$ and $340 \mathrm{~nm}$ for the others. All samples contain $0.5 \% \mathrm{THF} / \mathrm{MeOH}(1: 1 \mathrm{v} / \mathrm{v})$ to ensure solubility.
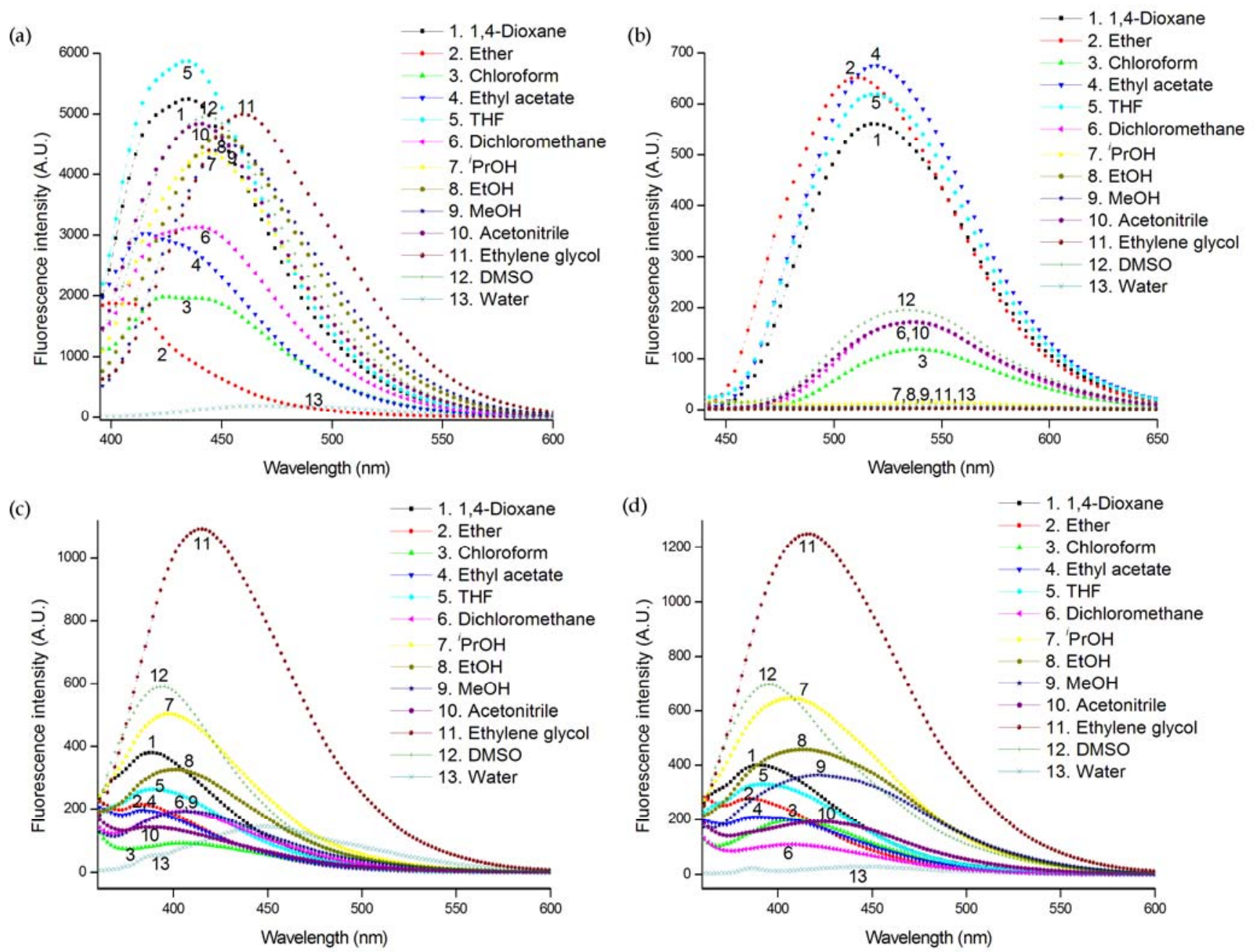

Table 1 summarizes the photophysical properties of nucleosides in thirteen different solvents. The fluorescence quantum yields $\left(\Phi_{\mathrm{F}}\right)$ of the nucleosides were determined using a $0.1 \mathrm{~N}$ aqueous $\mathrm{H}_{2} \mathrm{SO}_{4}$ solution of quinine sulfate $\left(\lambda_{\mathrm{ex}}=350 \mathrm{~nm}\right)$ as a standard [31]. There are some noteworthy features: (a) generally, the presence of a heteroatom in the fluorene unit of nucleoside $\mathbf{U}^{\mathbf{F O}}, \mathbf{U}^{\mathbf{D B F}}$, and $\mathbf{U}^{\text {DBT }}$ diminishes its fluorescence yield and fluorescence brightness (i.e., the product of its molar extinction coefficient and quantum yield) drastically when compared with $\mathbf{U}^{\mathbf{F L}}$. (2) $\mathbf{U}^{\text {DBF }}$ and $\mathbf{U}^{\mathbf{D B T}}$ showed very similar photophysical properties in various solvents. (3) The quantum yield and fluorescence brightness of nucleosides is highest in ${ }^{i} \mathrm{PrOH}$ for $\mathbf{U}^{\mathrm{FL}}$, ethyl acetate for $\mathbf{U}^{\mathrm{FO}}$, and ethylene glycol for $\mathbf{U}^{\mathbf{D B F}}$ and $\mathbf{U}^{\mathbf{D B T}}$. The lowest fluorescence brightness, however, was observed in ethylene glycol for $\mathbf{U}^{\mathbf{F O}}$ and water for $\mathbf{U}^{\mathbf{F L}}, \mathbf{U}^{\mathbf{D B F}}$, and $\mathbf{U}^{\mathbf{D B T}}$. These results indicate that the nucleosides exhibit highly solvent-dependent photophysical properties despite their structural similarities. $\mathbf{U}^{\text {Fo }}$, interestingly, exhibited a strong solvent dependency-namely, higher fluorescence brightness in aprotic solvents relative to those in protic solvents such as ${ }^{i} \mathrm{PrOH}, \mathrm{EtOH}, \mathrm{MeOH}$, ethylene glycol, and water which was attributable to the hydrogen bonding between the carbonyl group of $\mathbf{U}^{\mathrm{FO}}$ and solvent. 
Table 1. Photophysical characteristics of nucleosides in different solvents at $25^{\circ} \mathrm{C}$.

\begin{tabular}{|c|c|c|c|c|c|c|c|}
\hline Solvent & Compound & $E_{\mathrm{T}}(30)^{11}$ & $\begin{array}{c}\lambda_{\max } \\
(\mathrm{nm})^{\mathrm{a}}\end{array}$ & $\varepsilon\left(\mathrm{M}^{-1} \mathrm{~cm}^{-1}\right)$ & $\begin{array}{c}\lambda_{\mathrm{em}} \\
(\mathbf{n m})^{\mathrm{b}}\end{array}$ & $\Phi_{\mathrm{F}}{ }^{\mathrm{c}}$ & Brightness ${ }^{d}$ \\
\hline 1,4-Dioxane & $\mathbf{U}^{\mathrm{FL}}$ & 36 & 373 & 25,000 & 434 & 0.33 & 8,250 \\
\hline Ether & & 34.5 & 370 & 27,200 & 409 & 0.055 & 1,500 \\
\hline Chloroform & & 39.1 & 375 & 20,100 & 420 & 0.18 & 3,620 \\
\hline Ethyl acetate & & 38.1 & 371 & 19,900 & 414 & 0.14 & 2,790 \\
\hline THF & & 37.4 & 373 & 29,700 & 434 & 0.31 & 9,200 \\
\hline Dichloromethane & & 40.7 & 374 & 22,200 & 439 & 0.23 & 5,100 \\
\hline${ }^{i} \mathrm{PrOH}$ & & 48.4 & 370 & 20,900 & 444 & 0.50 & 10,500 \\
\hline $\mathrm{EtOH}$ & & 51.9 & 370 & 24,400 & 450 & 0.25 & 6,100 \\
\hline $\mathrm{MeOH}$ & & 55.4 & 369 & 25,100 & 453 & 0.26 & 6,530 \\
\hline Acetonitrile & & 45.6 & 370 & 26,200 & 440 & 0.28 & 7,340 \\
\hline Ethylene glycol & & 56.3 & 374 & 12,900 & 460 & 0.27 & 3,480 \\
\hline DMSO & & 45.1 & 377 & 27,100 & 443 & 0.18 & 4,880 \\
\hline Water & & 63.1 & 384 & 4,930 & 467 & 0.062 & 305 \\
\hline 1,4-Dioxane & $\mathbf{U}^{\mathrm{FO}}$ & 36 & 344 & 20,800 & 518 & 0.056 & 1,160 \\
\hline Ether & & 34.5 & 345 & 21,200 & 511 & 0.080 & 1,700 \\
\hline Chloroform & & 39.1 & 343 & 14,300 & 538 & 0.029 & 415 \\
\hline Ethyl acetate & & 38.1 & 343 & 19,400 & 519 & 0.090 & 1,750 \\
\hline THF & & 37.4 & 346 & 21,900 & 519 & 0.064 & 1,400 \\
\hline Dichloromethane & & 40.7 & 342 & 15,800 & 535 & 0.040 & 632 \\
\hline${ }^{i} \mathrm{PrOH}$ & & 48.4 & 344 & 16,500 & 552 & 0.0034 & 56.1 \\
\hline $\mathrm{EtOH}$ & & 51.9 & 343 & 16,300 & 554 & 0.00097 & 15.8 \\
\hline $\mathrm{MeOH}$ & & 55.4 & 342 & 17,900 & 558 & 0.0014 & 25.1 \\
\hline Acetonitrile & & 45.6 & 342 & 18,400 & 537 & 0.0219 & 403 \\
\hline Ethylene glycol & & 56.3 & 345 & 14,000 & 556 & 0.00076 & 10.6 \\
\hline DMSO & & 45.1 & 347 & 21,500 & 535 & 0.018 & 387 \\
\hline Water & & 63.1 & 341 & 13,200 & 552 & 0.0038 & 50.2 \\
\hline 1,4-Dioxane & $\mathbf{U}^{\mathrm{DBF}}$ & 36 & 328 & 23,300 & 388 & 0.049 & 1,140 \\
\hline Ether & & 34.5 & 327 & 27,300 & 383 & 0.029 & 792 \\
\hline Chloroform & & 39.1 & 317 & 17,100 & 404 & 0.086 & 1,470 \\
\hline Ethyl acetate & & 38.1 & 327 & 24,500 & 383 & 0.027 & 662 \\
\hline THF & & 37.4 & 329 & 24,700 & 388 & 0.035 & 865 \\
\hline Dichloromethane & & 40.7 & 328 & 21,400 & 405 & 0.044 & 942 \\
\hline${ }^{i} \mathrm{PrOH}$ & & 48.4 & 328 & 22,500 & 397 & 0.086 & 1,940 \\
\hline $\mathrm{EtOH}$ & & 51.9 & 327 & 24,300 & 401 & 0.074 & 1,800 \\
\hline $\mathrm{MeOH}$ & & 55.4 & 326 & 23,000 & 406 & 0.047 & 1,080 \\
\hline Acetonitrile & & 45.6 & 326 & 24,000 & 386 & 0.026 & 624 \\
\hline Ethylene glycol & & 56.3 & 329 & 21,300 & 415 & 0.23 & 4,900 \\
\hline DMSO & & 45.1 & $\mathrm{nd}^{\mathrm{e}}$ & $\mathrm{nd}^{\mathrm{e}}$ & 394 & 0.084 & $\mathrm{nd}^{\mathrm{e}}$ \\
\hline Water & & 63.1 & 325 & 11,700 & 449 & 0.047 & 550 \\
\hline 1,4-Dioxane & $\mathbf{U}^{\text {DBT }}$ & 36 & 327 & 26,500 & 390 & 0.047 & 1,250 \\
\hline Ether & & 34.5 & 325 & 28,900 & 358 & 0.020 & 578 \\
\hline Chloroform & & 39.1 & 329 & 20,500 & 407 & 0.050 & 1,030 \\
\hline
\end{tabular}


Table 1. Cont.

\begin{tabular}{|c|c|c|c|c|c|c|c|}
\hline Solvent & Compound & $E_{\mathrm{T}}(30)^{11}$ & $\begin{array}{c}\lambda_{\max } \\
(\mathbf{n m})^{\mathrm{a}}\end{array}$ & $\varepsilon\left(\mathrm{M}^{-1} \mathrm{~cm}^{-1}\right)$ & $\begin{array}{c}\lambda_{\mathrm{em}} \\
(\mathrm{nm})\end{array}$ & $\Phi_{\mathrm{F}} \mathrm{c}$ & Brightness ${ }^{d}$ \\
\hline 1,4-Dioxane & $\mathbf{U}^{\text {DBT }}$ & 36 & 327 & 26,500 & 390 & 0.047 & 1,250 \\
\hline Ethyl acetate & & 38.1 & 325 & 24,200 & 389 & 0.024 & 581 \\
\hline THF & & 37.4 & 326 & 24,900 & 391 & 0.033 & 822 \\
\hline Dichloromethane & & 40.7 & 327 & 24,600 & 408 & 0.029 & 713 \\
\hline${ }^{i} \mathrm{PrOH}$ & & 48.4 & 325 & 24,300 & 407 & 0.064 & 1,560 \\
\hline $\mathrm{EtOH}$ & & 51.9 & 326 & 22,900 & 411 & 0.061 & 1,400 \\
\hline $\mathrm{MeOH}$ & & 55.4 & 325 & 24,400 & 421 & 0.045 & 1,100 \\
\hline Acetonitrile & & 45.6 & 325 & 24,800 & 423 & 0.020 & 496 \\
\hline Ethylene glycol & & 56.3 & 328 & 21,900 & 417 & 0.11 & 2,410 \\
\hline DMSO & & 45.1 & $\mathrm{nd}^{\mathrm{e}}$ & $\mathrm{nd}^{\mathrm{e}}$ & 395 & 0.082 & $\mathrm{nd}^{\mathrm{e}}$ \\
\hline Water & & 63.1 & 324 & 8,600 & 451 & 0.0079 & 67.9 \\
\hline
\end{tabular}

${ }^{\mathrm{a}}$ Only the largest absorption maxima are listed; ${ }^{\mathrm{b}}$ Wavelength of emission maximum when excited at the absorption maximum; ${ }^{\mathrm{c}}$ Quantum efficiencies using $0.1 \mathrm{~N}$ aqueous $\mathrm{H}_{2} \mathrm{SO}_{4}$ solution of quinine sulfate as a standard, $\lambda_{\mathrm{ex}}=350 \mathrm{~nm}$. Data shown are the mean values of three independent experiments; ${ }^{\mathrm{d}}$ The fluorescence brightness $=\varepsilon \times \Phi_{\mathrm{F}} ;{ }^{\mathrm{e}}$ Not detectable due to overlapping absorption bands of a nucleoside and DMSO.

In polar solvents such as ${ }^{i} \mathrm{PrOH}, \mathrm{EtOH}, \mathrm{MeOH}$, acetonitrile, ethylene glycol, DMSO, and water substantially larger red-shifts in emission maxima of nucleosides were observed. Because it is instructive to calculate the magnitude of the expected spectral shifts due to solvent polarity effects, we plotted the fluorescence emission maxima and Stokes shifts $\left(v_{\mathrm{abs}}-v_{\mathrm{em}}\right)$ of nucleosides in thirteen different solvents against Reichardt's microscopic solvent parameter, $E_{\mathrm{T}}(30)$ (Figure 4) [32]. It is interesting to note that there is a linear correlation between emission maxima and $E_{\mathrm{T}}(30)$ regardless of the aproticity of the solvent. The red-shift of the fluorescence could be due to the significant difference between the excited-state charge distribution in the solute and the ground-state charge distribution, resulting in stronger interactions with polar solvents in the excited state.

Figure 4. Effect of $E_{\mathrm{T}}(30)$ on (a) the fluorescence emission maxima and (b) the Stokes shifts of nucleosides.
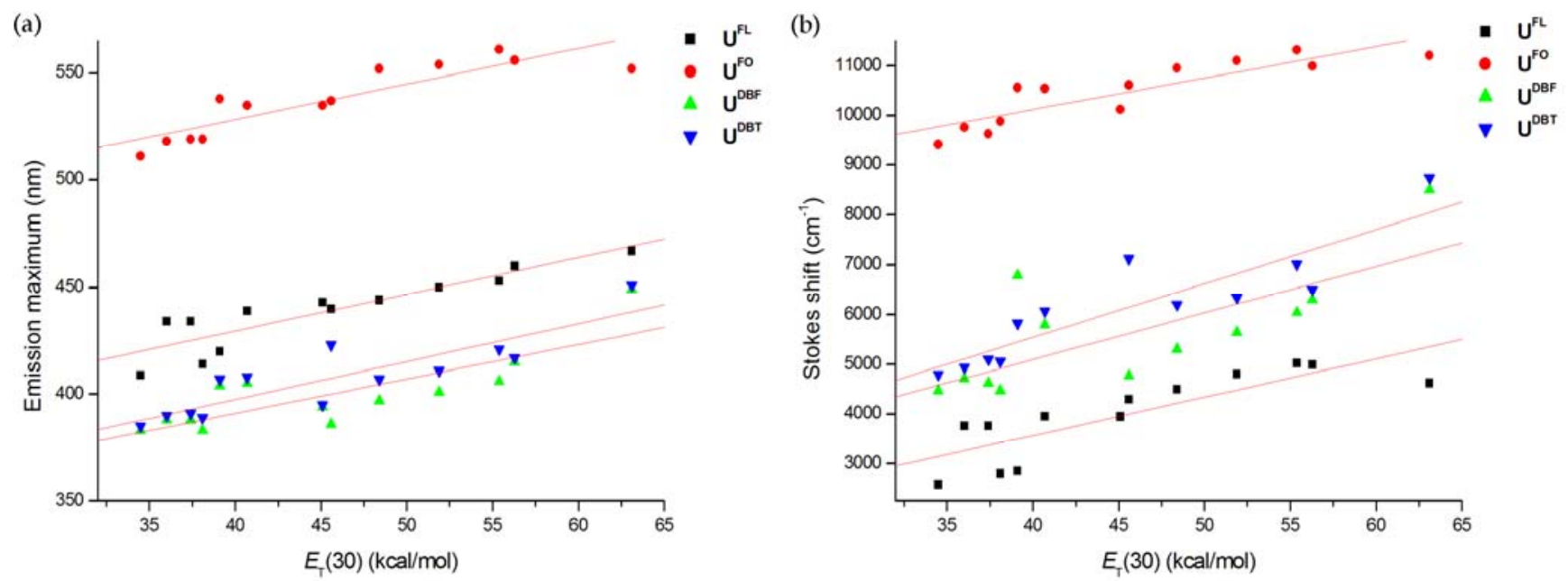
Emission maxima of $\mathbf{U}^{\mathbf{F O}}$ were red-shifted relative to those of other nucleosides. This higher Stokes shift of $\mathbf{U}^{\mathbf{F O}}$ is probably because the carbonyl group allows for hydrogen bonding and charge separation better than do the other nucleosides [30]. Interestingly, the Stokes shifts of $\mathbf{U}^{\mathbf{D B F}}$ and $\mathbf{U}^{\mathbf{D B T}}$ exhibited a more gradual shift to longer wavelengths with increasing solvent polarity compared to the slopes of other nucleosides, as shown in Figure 4b. In order to compare the sensitivity of our molecules of interest to environmental polarity with that of reported polarity-sensitive nucleosides [12,33], we examined the photophysical properties of fluorescent nucleosides in binary water/1,4-dioxane mixtures (Table S1, Figure 5), which is an established method for estimating the microenvironment polarity of fluorophores [34]. The Stokes shifts plotted against the $E_{\mathrm{T}}(30)$ values of the samples is shown in Figure 5. The slopes obtained from the linear plots indicated that $\mathbf{U}^{\mathbf{F O}}, \mathbf{U}^{\mathbf{D B F}}$, and $\mathbf{U}^{\mathbf{D B T}}$ are highly sensitive to environmental polarity and are comparable to the slopes of reported nucleosides such as pyridine- and furan-labeled uridines. $\mathbf{U}^{\mathbf{D B F}}$ and $\mathbf{U}^{\mathbf{D B T}}$ revealed a seemingly exponential trend, leading us to conclude that a more appropriate expression for the interactions between these nucleosides and solvents should be explored.

Figure 5. Dependence of the Stokes shift of nucleosides in water/1,4-dioxane binary solvent mixture on the empirical solvent polarity parameter, $E_{\mathrm{T}}(30)$.

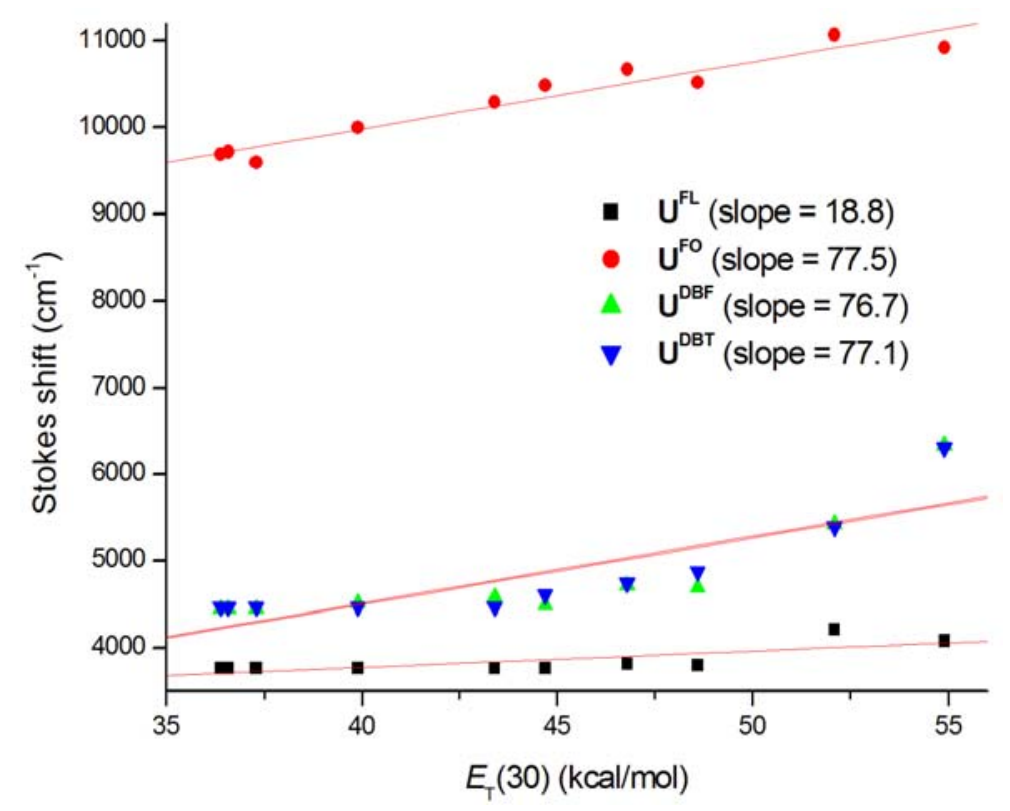

\section{Experimental}

\subsection{General}

All reactions were performed in dry glassware under Ar atmospheres. Analytical thin layer chromatography (TLC) was performed using Merck $60 \mathrm{~F}_{254}$ silica gel plates; column chromatography was performed using Merck 60 silica gel (230-400 mesh). Melting points were determined using an Electrothermal IA 9000 series melting point apparatus and are uncorrected. Infrared (IR) spectra were recorded using a JASCO FT/IR-4100 spectrometer. ${ }^{1} \mathrm{H}$ - and ${ }^{13} \mathrm{C}-\mathrm{NMR}$ spectra were recorded using a Bruker NMR spectrometer (AVANCE digital $400 \mathrm{MHz}$ ). High-resolution electron impact (EI) mass spectra were recorded using a JEOL JMS-700 mass spectrometer at the Daegu center of KBSI, Korea. 


\subsection{Materials}

All commercially available chemicals were used without further purification; solvents were carefully dried and distilled prior to use. 3-Bromobenzofuran (1) [35] and 3-ethynyldibenzothiophene (3b) [29] have been reported previously. $\mathbf{U}^{\mathrm{FL}}$ and $\mathbf{U}^{\mathrm{FO}}$ were synthesized according to the reported protocol [9-11].

\subsection{Preparation of 3-[2-(Trimethylsilyl)ethynyl]dibenzofuran (2)}

A solution of 1 [35] (580 mg, $2.35 \mathrm{mmol}),\left(\mathrm{PPh}_{3}\right)_{2} \mathrm{PdCl}_{2}$ (165 mg, $\left.0.235 \mathrm{mmol}\right)$, and $\mathrm{CuI}(44.8 \mathrm{mg}$, $0.235 \mathrm{mmol})$ in THF $(12 \mathrm{~mL})$ and $\mathrm{Et}_{3} \mathrm{~N}(3.9 \mathrm{~mL})$ was degassed with nitrogen. Trimethylsilylacetylene $\left(500 \mu \mathrm{L}, 3.52 \mathrm{mmol}\right.$ ) was added at $50{ }^{\circ} \mathrm{C}$ and the mixture stirred for $4 \mathrm{~h}$. After evaporation of solvent in vacuo, the residue was subjected to chromatography on a silica gel column with hexane as eluent to give 2 (380 mg, 61\%): M.p. $110-113{ }^{\circ} \mathrm{C}$; IR (film): $v$ 3063, 2954, 2896, 2144, 1453, 1416, 1340, 1315, 1248, 1201, 1133, 940, 831, 743, $629 \mathrm{~cm}^{-1} ;{ }^{1} \mathrm{H}-\mathrm{NMR}\left(\mathrm{CDCl}_{3}\right): \delta 7.93(\mathrm{dq}, J=8.0,0.67 \mathrm{~Hz}, 1 \mathrm{H} ; \mathrm{H}-6)$, $7.86(\mathrm{dd}, J=8.0,0.40 \mathrm{~Hz}, 1 \mathrm{H} ; \mathrm{H}-1), 7.67$ (q, $J=0.80 \mathrm{~Hz}, 1 \mathrm{H} ; \mathrm{H}-4), 7.57$ (dt, $J=8.0,0.80 \mathrm{~Hz}, 1 \mathrm{H}$; H-2), 7.49-7.45 (m, 2H; H-7 and H-9), 7.35 (td, $J=7.4,0.80 \mathrm{~Hz}, 1 \mathrm{H} ; \mathrm{H}-8), 0.29$ (s, 9H; $\mathrm{SiCH}_{3}$ ); ${ }^{13} \mathrm{C}-\mathrm{NMR}\left(\mathrm{CDCl}_{3}\right): \delta 156.9,155.7$ 127.8, 127.1, 124.8, 123.9, 123.1, 121.8, 121.0, 120.5, 115.3, 111.9, 105.3, 95.0, 0.1; HRMS-EI $(\mathrm{m} / \mathrm{z})$ : [M] $]^{+}$calcd for $\mathrm{C}_{17} \mathrm{H}_{16} \mathrm{OSi} 264.0970$; found, 264.0968.

\subsection{Preparation of 3-Ethynyldibenzofuran (3a)}

A solution of $2(600 \mathrm{mg}, 2.27 \mathrm{mmol})$ and $\mathrm{K}_{2} \mathrm{CO}_{3}(345 \mathrm{mg}, 2.25 \mathrm{mmol})$ in $\mathrm{MeOH}(6.7 \mathrm{~mL})$ and $\mathrm{THF}$ $(6.7 \mathrm{~mL})$ was stirred at $\mathrm{rt}$ for $5 \mathrm{~h}$. After evaporation of the solvent in vacuo, dichloromethane and water were added and the product was extracted into the organic phase which was then concentrated. The residue was purified by chromatography $\left(\mathrm{SiO}_{2}\right.$; hexane/EtOAc, 10:1) to give 3a (385 mg, 88\%): M.p. 83-86 ${ }^{\circ} \mathrm{C}$; IR (film): $v$ 3264, 2920, 2854, 2098, 1641, 1595, 1446, 1364, 1193, 1107, 926, 880, 821, 742, 666, $606 \mathrm{~cm}^{-1} ;{ }^{1} \mathrm{H}-\mathrm{NMR}\left(\mathrm{CDCl}_{3}\right): \delta 7.94$ (dq, $\left.J=7.4,0.8 \mathrm{~Hz}, 1 \mathrm{H} ; \mathrm{H}-6\right), 7.89$ (dd, $J=8.0,0.8 \mathrm{~Hz}$, $1 \mathrm{H} ; \mathrm{H}-1), 7.70$ (q, $J=0.53 \mathrm{~Hz}, 1 \mathrm{H} ; \mathrm{H}-4), 7.58$ (dt, $J=8.0,0.8 \mathrm{~Hz}, 1 \mathrm{H} ; \mathrm{H}-2), 7.50-7.46$ (m, 2H: H-7 and $\mathrm{H}-9), 7.36(\mathrm{td}, J=7.4,0.80 \mathrm{~Hz}, 1 \mathrm{H} ; \mathrm{H}-8), 3.17(\mathrm{~s}, 1 \mathrm{H} ; \mathrm{CCH}) ;{ }^{13} \mathrm{C}-\mathrm{NMR}\left(\mathrm{CDCl}_{3}\right): \delta 156.9,155.7$, 127.9, 127.1, 125.1, 123.8, 123.2, 121.1, 120.7, 120.6, 115.5, 111.6, 83.9, 77.8; HRMS-EI $(m / z):[M]^{+}$ calcd for $\mathrm{C}_{14} \mathrm{H}_{8} \mathrm{O}$ 192.0575; found, 192.0573 .

\subsection{General Procedure for Nucleoside Synthesis}

$\left(\mathrm{PPh}_{3}\right)_{2} \mathrm{PdCl}_{2}(36.5 \mathrm{mg}, 0.0520 \mathrm{mmol})$ and $\mathrm{CuI}(9.9 \mathrm{mg}, 0.0520 \mathrm{mmol})$ were added to a solution of 2'-deoxy-5-iodouridine 2 (184 mg, $0.520 \mathrm{mmol})$ and 2-ethynylfluorene derivative $3(0.520 \mathrm{mmol})$ in $\mathrm{Et}_{3} \mathrm{~N}(2.6 \mathrm{~mL})$ and THF $(7.8 \mathrm{~mL})$. Argon was bubbled through the mixture for $2 \mathrm{~min}$ before the mixture was subjected 10 times to a pump/purge cycle, and then it was stirred at $\mathrm{rt}$ for $4 \mathrm{~h}$. After evaporation of solvent in vacuo, the residue was subjected to chromatography $\left(\mathrm{SiO}_{2} ; \mathrm{CH}_{2} \mathrm{Cl}_{2} / \mathrm{MeOH}\right.$, $40: 1)$ to yield $\mathbf{U}^{\text {DBF }}$ (41\%) or $\mathbf{U}^{\text {DBF }}(44 \%)$.

2'-Deoxy-5-(3-dibenzofuranylethynyl)uridine (U $\left.{ }^{\text {DBF }}\right)$. M.p. $>164{ }^{\circ} \mathrm{C}$ dec.; IR (film): $v$ 3383, 3162, $3049,2922,2855,1664,1455,1275,1195,1099,987,860,740,633 \mathrm{~cm}^{-1} ;{ }^{1} \mathrm{H}-\mathrm{NMR}$ (DMSO- $\left.d_{6}\right): \delta$ $11.74(\mathrm{~s}, 1 \mathrm{H} ; \mathrm{NH}), 8.46(\mathrm{~s}, 1 \mathrm{H} ; \mathrm{H}-6), 8.18(\mathrm{dd}, J=7.8,0.60 \mathrm{~Hz}, 2 \mathrm{H} ; \mathrm{DBF}-\mathrm{H}), 7.81$ (q, 
$J=0.67 \mathrm{~Hz}, 1 \mathrm{H}$; DBF-H), 7.74-7.72 (m, 1H; DBF-H), 7.58-7.54 (m, 1H; DBF-H), 7.51 (dd, $J=7.8$, $1.4 \mathrm{~Hz}, 2 \mathrm{H}$; DBF-H), 7.43 (td, $J=7.3,0.6 \mathrm{~Hz}, 1 \mathrm{H}$; DBF-H), 6.15 (t, $\left.J=6.4 \mathrm{~Hz}, 1 \mathrm{H} ; \mathrm{H}-1^{\prime}\right), 5.30$ (d, $\left.J=4.4 \mathrm{~Hz}, 1 \mathrm{H} ; \mathrm{OH}-3^{\prime}\right), 5.23$ (t, $\left.J=4.8 \mathrm{~Hz}, 1 \mathrm{H} ; \mathrm{OH}-5^{\prime}\right), 4.30-4.26\left(\mathrm{~m}, 1 \mathrm{H} ; \mathrm{H}-3^{\prime}\right), 3.83$ (q, $J=3.3 \mathrm{~Hz}$, $1 \mathrm{H}$; H-4'), 3.71-3.59 (m, 2H; H-5'), 2.20-2.17 (m, 2H; H-2'); ${ }^{13} \mathrm{C}-\mathrm{NMR}$ (DMSO-d $)$ ): $\delta$ 161.5, 156.1, 155.1, 149.5, 144.2, 131.6, 128.3, 126.5, 124.0, 123.5, 123.1, 121.6, 121.3, 114.3, 111.8, 98.1, 92.0, 87.6, 84.9, 83.3, 69.9, 60.8; HRMS-EI (m/z): [M] ${ }^{+}$calcd for $\mathrm{C}_{23} \mathrm{H}_{18} \mathrm{~N}_{2} \mathrm{O}_{6}, 418.1165$; found, 418.1167 .

2'-Deoxy-5-(3-dibenzothiophenylethynyl)uridine ( $\left.\mathbf{U}^{\text {DBT }}\right)$. M.p. $>165^{\circ} \mathrm{C}$ dec.; IR (film): $v$ 3377, 3155, 3053, 2923, 2852, 1660, 1455, 1272, 1228, 1195, 1094, 987, 919, 825, 747, $635 \mathrm{~cm}^{-1}$; ${ }^{1} \mathrm{H}-\mathrm{NMR}$ $\left(\mathrm{DMSO}-d_{6}\right): \delta 11.72(\mathrm{~s}, 1 \mathrm{H} ; \mathrm{NH}), 8.46(\mathrm{~s}, 1 \mathrm{H} ; \mathrm{H}-6), 8.40-8.38(\mathrm{~m}, 2 \mathrm{H} ; \mathrm{DBT}-\mathrm{H}), 8.178$ (dd, $J=1.4,0.60 \mathrm{~Hz}, 1 \mathrm{H}$; DBT-H), 8.07-8.04 (m, 1H; DBT-H), 7.58 (dd, $J=8.2,1.4 \mathrm{~Hz}, 1 \mathrm{H}$; DBT-H), $7.55-7.53$ (m, 2H; DBT-H), 6.144 (t, $\left.J=6.402,1 \mathrm{H} ; \mathrm{H}^{\prime} 1^{\prime}\right), 5.30$ (d, $\left.J=4.4 \mathrm{~Hz}, 1 \mathrm{H} ; \mathrm{OH}-3^{\prime}\right), 5.23$ (t, $\left.J=4.6 \mathrm{~Hz}, 1 \mathrm{H} ; \mathrm{OH}-5^{\prime}\right), 4.30-4.26$ (m, 1H; H-3'), 3.83 (q, $\left.J=3.3 \mathrm{~Hz}, 1 \mathrm{H} ; \mathrm{H}-4^{\prime}\right), 3.71-3.59$ (m, 2H; H-5'), 2.20-2.16 (m, 2H; H-2'); ${ }^{13} \mathrm{C}-\mathrm{NMR}$ (DMSO- $\left.d_{6}\right): \delta 161.6,149.6,144.2,139.3,138.9,135.0$, 134.5, 127.6, 125.7, 125.0, 123.2, 122.4, 122.2, 120.9, 98.1, 91.9, 87.6, 84.9, 83.5, 79.2, 69.9, 60.8, 55.0; HRMS-EI $(\mathrm{m} / \mathrm{z})$ : [M] $]^{+}$calcd for $\mathrm{C}_{23} \mathrm{H}_{18} \mathrm{~N}_{2} \mathrm{O}_{5} \mathrm{~S}$, 434.0936; found, 434.0935.

\subsection{UV and Fluorescence Measurements}

Ultraviolet (UV) spectra were recorded using a Cary 100 UV-Vis spectrophotometer and 10-mm-path quartz cell, with respect to a pure-solvent reference. Fluorescence spectra were recorded using a Hitachi F4500 spectrofluorometer. All samples were prepared from a stock solution in $\mathrm{THF} / \mathrm{MeOH}$ $(1: 1 \mathrm{v} / \mathrm{v})$ to ensure solubility, and hence, all samples contain $0.5 \% \mathrm{THF} / \mathrm{MeOH}(1: 1 \mathrm{v} / \mathrm{v})$. The excitation and emission bandwidth was $1 \mathrm{~nm}$. The fluorescence quantum yields $\left(\Phi_{\mathrm{F}}\right)$ were determined using $0.1 \mathrm{~N}$ aqueous $\mathrm{H}_{2} \mathrm{SO}_{4}$ solution of quinine sulfate as a reference [31].

\section{Conclusions}

We designed structurally similar fluorescent 2'-deoxyuridine derivatives that exhibit solvent-dependent photophysical properties via drastic changes in emission intensity as well as emission wavelength. These microenvironment-sensitive nucleosides may be used as probes for investigating nucleic acid dynamics and the recognition process. A deeper understanding of how the photophysical properties relate to chemical structures may allow for the design of ideal environmentally sensitive fluorescent nucleosides towards the development of DNA probes. Efforts in these directions are currently in progress.

\section{Supplementary Materials}

Supplementary materials can be accessed at: http:/www.mdpi.com/1420-3049/17/10/12061/s1.

\section{Acknowledgments}

This research was supported by Basic Science Research Program through the National Research Foundation of Korea (NRF) funded by the Ministry of Education, Science and Technology (2010-0007605 and 2012-0002831). 


\section{References}

1. Ranasinghe, R.T.; Brown, T. Fluorescence based strategies for genetic analysis. Chem. Commun. 2005, 5487-5502.

2. Wilson, J.N.; Kool, E.T. Fluorescent DNA base replacements: Reporters and sensors for biological systems. Org. Biomol. Chem. 2006, 4, 4265-4274.

3. Venkatesan, N.; Seo, Y.J.; Bang, E.K.; Park, S.M.; Lee, Y.S.; Kim, B.H. Chemical modification of nucleic acids toward functional nucleic acid systems. Bull. Korean Chem. Soc. 2006, 28, 613-630.

4. Venkatesan, N.; Seo, Y.J.; Kim, B.H. Quencher-free molecular beacons: A new strategy in fluorescence based nucleic acid analysis. Chem. Soc. Rev. 2008, 37, 648-663.

5. Dodd, D.W.; Hudson, R.H.E. Intrinsically fluorescent base-discriminating nucleoside analogs. Mini-Rev. Org. Chem. 2009, 6, 378-391.

6. Sinkeldam, R.W.; Greco, N.J.; Tor, Y. Fluorescent analogs of biomolecular building blocks: Design, properties, and applications. Chem. Rev. 2010, 110, 2579-2619.

7. Dai, N.; Kool, E.T. Fluorescent DNA-based enzyme sensors. Chem. Soc. Rev. 2011, 40, 5756-5770.

8. Østergaard, M.E.; Hrdlicka, P.J. Pyrene-functionalized oligonucleotides and locked nucleic acids (LNAs): Tools for fundamental research, diagnostics, and nanotechnology. Chem. Soc. Rev. 2011, 40, 5771-5788.

9. Hwang, G.T.; Seo, Y.J.; Kim, B.H. A highly discriminating quencher-free molecular beacon for probing DNA. J. Am. Chem. Soc. 2004, 126, 6528-6529.

10. Ryu, J.H.; Seo, Y.J.; Hwang, G.T.; Lee, J.Y.; Kim, B.H. Triad base pairs containing fluorene unit for quencher-free SNP typing. Tetrahedron 2007, 63, 3538-3547.

11. Ryu, J.H.; Heo, J.Y.; Bang, E.-K.; Hwang, G.T.; Kim, B.H. Quencher-free linear beacon systems containing 2-ethynylfluorenone-labeled 2'-deoxyuridine units. Tetrahedron 2012, 68, 72-78.

12. Sinkeldam, R.W.; Greco, N.J.; Tor, Y. Polarity of major grooves explored by using an isosteric emissive nucleoside. ChemBioChem 2008, 9, 706-709.

13. Østergaard, M.E.; Guenther, D.C.; Kumar, P.; Baral, B.; Deobald, L.; Paszczynski, A.J.; Sharma, P.K.; Hrdlicka, P.J. Pyrene-functionalized triazole-linked 2'-deoxyuridines-probes for discrimination of single nucleotide polymorphisms (SNPs). Chem. Commun. 2010, 46, 4929-4931.

14. Varghese, R.; Wagenknecht, H.-A. Non-covalent versus covalent control of self-assembly and chirality of Nile red-modified nucleoside and DNA. Chem. Eur. J. 2010, 16, 9040-9046.

15. Bag, S.S.; Kundu, R.; Matsumoto, K.; Saito, Y.; Saito, I. Singly and doubly labeled base-discriminating fluorescent oligonucleotide probes containing oxo-pyrene chromophore. Bioorg. Med. Chem. Lett. 2010, 20, 3227-3230.

16. Pawar, M.G.; Srivatsan, S.G. Synthesis, photophysical characterization, and enzymatic incorporation of a microenvironment-sensitive fluorescent uridine analog. Org. Lett. 2011, 13, 1114-1117.

17. Saito, Y.; Miyamoto, S.; Suzuki, A.; Matsumoto, K.; Ishihara, T.; Saito, I. Fluorescent nucleosides with "on-off" switching function, $\mathrm{pH}$-responsive fluorescent uridine derivatives. Bioorg. Med. Chem. Lett. 2012, 22, 2753-2756.

18. Tanaka, M.; Oguma, K.; Saito, Y.; Saito, I. Enhancement of fluorescence quenching and exciplex formation in DNA major groove by double incorporation of modified fluorescent deoxyuridines. Bioorg. Med. Chem. Lett. 2012, 22, 4103-4106. 
19. Barrois, S.; Beyer, C.; Wagenknecht, H.-A. Covalent modification of 2'-deoxyuridine with two different molecular switches. Synlett 2012, 23, 711-716.

20. Tanaka, M.; Oguma, K.; Saito, Y.; Saito, I. Drastic enhancement of excess electron-transfer efficiency through DNA by inserting consecutive 5-phenylethynyl-2'-deoxyuridines as a modulator. Chem. Commun. 2012, 48, 9394-9396.

21. Parker, C.A. Photoluminescence of Solutions; Elsevier: Amsterdam, The Netherlands, 1968.

22. Saito, Y.; Koda, M.; Shinohara, Y.; Saito, I. Synthesis and photophysical properties of 8-arylbutadienyl 2'-deoxyguanosines. Tetrahedron Lett. 2011, 52, 491-494.

23. Saito, Y.; Shinohara, Y.; Ishioroshi, S.; Suzuki, A.; Tanaka, M.; Saito, I. Synthesis of environmentally sensitive 2'-deoxyguanosine containing solvatochromic pyrene dluorophore. Tetrahedron Lett. 2011, 52, 2359-2361.

24. Panozzo, S.; Vial, J.-C.; Kervella, Y.; Stéphan, O. Fluorene-fluorenone copolymer: Stable and efficient yellow-emitting material for electroluminescent devices. J. Appl. Phys. 2002, 92, 3495-3502.

25. Józefowicz, M. Determination of reorganization energy of fluorenone and 4-hydroxyfluorenone in neat and binary solvent mixtures. Spectrochim. Acta A 2007, 67, 444-449.

26. Nguyen, D.D.; Trunk, J.; Nakhimovsky, L.; Spanget-Larsen, J. Electronic transitions of fluorene, dibenzofuran, carbazole, and dibenzothiophene: From the onset of absorption to the ionization threshold. J. Mol. Spectrosc. 2010, 264, 19-25.

27. Sonogashira, K.; Tohda, Y.; Hagihara, N. A convenient synthesis of acetylenes: Catalytic substitutions of acetylenic hydrogen with bromoalkenes, iodoarenes and bromopyridines. Tetrahedron Lett. 1975, 16, 4467-4470.

28. Hwang, G.T.; Son, H.S.; Ku, J.K.; Kim, B.H. Synthesis and photophysical studies of bisenediynes as tunable fluorophores. J. Am. Chem. Soc. 2003, 125, 11241-11248.

29. Sekine, C.; Ishitobi, M.; Iwakura, K.; Minai, M.; Fujisawa, K. Novel high birefringence dibenzothiophenylacetylene liquid crystals. Liq. Cryst. 2002, 29, 355-367.

30. Lakowicz, J.R. Principles of Fluorescence Spectroscopy, 3rd ed.; Springer: New York, NY, USA, 2006; pp. 205-235.

31. Eastman, J.W. Quantitative spectrofluorimetry-The fluorescence quantum yield of quinine sulfate. Photochem. Photobiol. 1967, 6, 55-72.

32. Reichardt, C. Solvatochromic dyes as solvent polarity indicators. Chem. Rev. 1994, 94, 2319-2358.

33. Sinkeldam, R.W.; Marcus, P.; Uchenik, D.; Tor, Y. Multisensing emissive pyrimidine. Chem. Phys. Chem. 2011, 12, 2260-2265.

34. Sinkeldam, R.W.; Tor, Y. To D or not to D? On estimating the microenvironment polarity of biomolecular cavities. Org. Biomol. Chem. 2007, 5, 2523-2528.

35. Cullinane, N.M.; Padfield, H.J.H. Investigations in the diphenylene oxide series. Part V. J. Chem. Soc. 1935, 1131-1134.

Sample Availability: Samples of the compounds used in this study are available from the authors.

(C) 2012 by the authors; licensee MDPI, Basel, Switzerland. This article is an open access article distributed under the terms and conditions of the Creative Commons Attribution license (http://creativecommons.org/licenses/by/3.0/). 